\title{
AFRIKA DIE ONBEKENDE. DIE PROTESTANTISME IN AFRIKA.*
}

\section{HISTORIESE ONTWIKKELING.}

1. Die Negentiende Eeu.

Hoewel reeds in die $17 \mathrm{de}$ eeu 'n gereformeerde sending onder beheer van die Nederlandse Oos-Indiese Kompanjie in Afrika begin is en sedert die laaste kwart van die $18 \mathrm{e}$ eeu 'n lewendige sendingaksie van die piëtistiese Hernhutters van Moravië uitgegaan het, is die groot stoot tot daadwerklike en wydverspreide sendingaksie eers gegee na die metodistiese sogenaamde ,Great Awakening", waarna sedert 1892 'n aanvang geneem is met genootskaplike sending vanuit Engeland, waarop gevolg het 'n uitbreiding van sodanige sending in Afrika vanuit alle Protestantse lande van Europa en Amerika, totdat teen 1890 reeds 106 sulke genootskappe en kerke sendingwerk in Afrika gedoen het.

Die tweede groot stoot het gekom na die verdeling in 1880 van Afrika onder verskillende Europese moondhede.

Veral die Engelse sending, maar ten dele ook die Duitse sending, het toe meer 'n politieke kleur aangeneem. In Engeland was dit veral die groot sen. ding- en ontdekkingsreisiger David Livingstone wat sedert omstreeks 1856 voor die verbaasde oë van Engeland die ontsaglike moontlikhede van die toe nog so onbekende donker kontinent aan die lig gestel het. Vir hom was dit 'n uitgemaakte saak dat die uitgebreide en so skadelike slawehandel alleen doeltreffend bestry kon word as in die plek daarvan gestel kon word die gewone handel, en terselfdertyd was hy van oordeel dat met die uitbreiding van die Engelse handel die weg ook gebaan sou word vir die ingang en verdere uitbreiding van die Christendom.

Andersyds is die hoop gekoester dat die sending selfs die wegbereider vir - die uitbreiding van die Britse ryk kon wees.

Die sending het vir Livingstone geword die ,spiritual expansion of the Empire".

Aangesien die tyd van die wêreldwye uitbreiding van die kerk saamgeval het met die tyd van die wêreldwye kapitalisties-imperialistiese ekspansie, het hierdie so ongesonde verbinding nie nagelaat om sy nadelige uitwerking op die sendingwerk en die nie-blankes van Afrika te hê nie.

Sending en Engelse kultuur en beskawing is beskou as twee bondgenote, en dit is as vanselfsprekend annvaar dat die nie-blankes van Afrika en hulle kulture geassimileer moes word

\footnotetext{
* Lesing gehou voor die Afrika-Seminaar, P.U. vir C.H.O.
} 
met die allesoorheersende Engelse ekwivalente.

Die derde groot sendingperiode het so omstreeks 1890 begin en aangehou tot ongeveer 1914. Toe het daar 'n algemene gees van blye optimisme geheers, en die verwagting is gekoester dat die Europese beskawing en die Christendom oor die hele wêreld sou uitbrei, en daar is gespreek van die ,evangelization of the world in this generation". Die sendingsaak het nou populêr geword en die sendingwerk is op ongekende skaal oral in Afrika uitgebrei, sodat daar in 1914 reeds 222 sendinggenootskappe en kerke en oor die 4,000 Protestantse sendelinge in Afrika in die veld was.

Die volgende onbevooroordeelde $\mathrm{kri}$ tiek van die bekende missioloog C. P. Groves oor die sending van die $19 \mathrm{de}$ eeu is heeltemal geregverdig: „Die sendeling het slegs sy eie godsdiens en kultuur en beskawing geken en daarom wou hy dit net so in Afrika oorplant. Al die erfgoed van die naturelle is as onbruikbaar beskou, en vir die Engelse sendeling was dit vanselfsprekend dat die baie sosiale gewoontes wat so nou verbind is met die Christendom aan die naturelle oorhandig sou word. Die enigste beleid moes dus wees vervanging, denasionalisering „with a vengeance"."

2. Die Twintigste Eeu vanaf 1914 . (a) 1914-1938:

Maar in hierdie optimistiese verwagtinge is die Protestantse sendingwêreld deur die eerste wêreldoorlog wreed ontnugter; die Europese beskawing het so 'n sekularistiese karakter aangeneem dat dit nie meer gesien is as ' $n$ bondgenoot van die sending nie maar as 'n vyand. Daarbenewens is die inheemse kulture en samelewingsverbande by die gemeenskappe, wat reeds jarelank in kontak was met die sendingwerk, so ontwrig dat algemeen gevoel is dat 'n nuwe sendingmetode toegepas sou moet word.

'n Sendingkonferensie van deelnemende kerke in Afrika is in 1926 te Le Zoutu belê, en daar is besluit dat in die sendingwerk so nou moontlik by die inheemse kulture aangesluit en op die wortel daarvan voortgebou moes word.

Maar terselfdertyd is, as gevolg van die destyds heersende gees van relativisme teenoor die heidense godsdienste, ongelukkig ook as beleid aanvaar om by die waardevolle in die heidense godsdienste aan te pas en verder voort te bou.

Teen hierdie relativisme en subjektivisme in die godsdiens het daar veral na $K$. Barth se besliste standpunt oor die absoluutheid van God en sy openbaring en die sondige van die menslike, 'n reaksie ontstaan. 'n Internasionale sendingkonferensie is vir 1938 te Jerusalem belê en ter voorbereiding hiervan is aan dr. H. Kraemer opgedra om as handleiding vir die konferensie die nodige riglyne vir die juiste sendingmetode aan te dui. Hy doen dit in sy monumentale werk The Christian message in a non-Christian world, waarin hy 'n suiwere klank laat hoor teenoor die relativisme en die kerk terugroep tot die fondamente van die Woord van God. Deur hierdie boek van hom en sy sterk optrede op die konferensie besluit hierdie groot internasionale vergadering dat die beginsels en metode vir die sen- 
ding uit die Skrif geput moes word.

Sedertdien is ' $n$ taamlik behoudende rigting in die Protestantse sending in Afrika gevolg, maar die aanslae van die "Great Society" het so sterk geword dat mettertyd aangeneem is dat dit alle inheemse kulture sou gelyk maak tot die een wêreldkultuur en dat dit dus nie die moeite sou loon om die inheemse kulture nog aan die lewe te hou nie.

(b) 1938-1959:

Die sendingwerksaamhede is intussen nog steeds verder uitgebrei; en nieteenstaande twee wêreldoorloë met al die ellende en ontwrigting wat dit meegebring het, was die uitbreiding sedert 1914 nog groter as gedurende die hele eeu daarvoor.

$\mathrm{Na}$ die tweede wêreldoorlog het dinge vinnig ontwikkel, en toestande verander nog steeds by die dag. Die nasionale ontwaking by die inheemse stamme het soos 'n veldbrand oor die kontinent voortgewoed, die een na die ander bevolkingsgroep word onafhanklik en dit word gevrees dat die sending van die Europese kerke geskei kan word van die jonger kerke in Afrika, wat al meer selfstandig word.

Die vraag is gestel wat die wese van sending dan is as sodanige ontwikkeling plaasvind, en hoe die verband moet wees tussen die ouer en jonger kerke. Daar is besef dat teenoor die voortvretende onchristelike sekularisasie en die nuwe toestande in die sending 'n prinsipiële stelling ingeneem moes word, en dat daarvoor dieper gegrawe moes word om tot by die wortel van die saak te kom. Vervolgens is op die Internasionale Sendingkonferensie te Willingen (1952) enige skriftuurlike rig- lyne in hierdie verband aangedui en is die sending gesien as die gesamentlike taak van die jonger en ouer kerke, wat die een universele kerk vorm.

Maar dit het duidelik geword dat die nasionale ontwaking wat betref die sending daarop neerkom dat in alle opsigte gelykheid met blankes en blanke kerke geëis word en dat vir die nieblanke kerke 'n gelykwaardige status met dié van die blanke kerke geëis word; verder moet daarna gestrewe word dat die kerke in alle opsigte voldoen aan die vereiste moderne standaarde; maar hierdie moderne ontwikkeling moet aanpas by die eie en 'n eiesoortige karakter dra en langs eie lyne geskied.

So word dan nou weer daarna gestrewe om die Protestantse kerke in Afrika 'n inheemse kleur en karakter te laat aanneem en om die eiendomlikhede van die nie-blanke gemeenskappe sover moontlik te waardeer.

So is daar dan hierdie skynbare paradoks - dat in hierdie krisistyd, waarin dit wil voorkom of die sendingmoontlikheid al meer ingeperk kan word, die Protestantse kerke gekom het tot 'n taamlik skriftuurlik suiwere opvatting oor wat die taak van die sending is en dat, nou dat die sekularisties-kosmopolitiese inwerking op sy sterkste is, daar allerweë weer gevra word na die eie.

Die vraag is egter of die skade wat in die verlede deur die so lang volgehoue sendingmetode en praktyk aangerig is, weer so gou onder hierdie so vinnig wisselende omstandighede van die moderne tyd herstel en met welslae 'n nuwe rigting ingeslaan kan word. 


\section{DIE REsUltate.}

\section{Die Uitbreiding.}

- Ten spyte van die ongesonde in die sendingpraktyk, en die ontwrigtende uitwerking van die twee wêreldoorloë, die alles deurdringende onchristelike sekularisasie van die Weste en die groeiende spanning in rasseverhoudinge, was die kwantitatiewe vooruitgang op sendingarbeid, in vergelyking met dié in ander kontinente gedurende die 20ste eeu, fenomenaal en die 20ste eeu kan in hierdie opsig, wat Afrika betref, met reg die wondereeu genoem word.

Hoewel baie gebiede nog onbeset is en daar nog 'n groot tekort is aan geskikte sendingkragte, het die geskatte getal van 1,800,000 Protestante in Afrika in 1925 tot ongeveer 14 miljoen vermeerder in 1957 , dus byna agt maal soveel in 32 jaar.

Maar die groei van die Rooms-Katolieke kerk was nog vinniger. Hierdie kerk het sy sendingwerksaamhede sedert 1870 geweldig uitgebrei in Afrika en die aantal aanhangers het van ongeveer $1,200,000$ in 1900 tot ongeveer 16 miljoen in 1957 vermeerder, dus byna twaalf maal soveel.

Van die ongeveer 223 miljoen mense is $\mathrm{na}$ skatting ongeveer 16 miljoen Rooms-Katolieke, 14 miljoen Protestante (in beide gevalle blankes ingesluit) en ongeveer 5 miljoen lede van die Koptiese kerk, dus ongeveer $16 \%$ van die totale bevolking gaan deur vir Christene.

Hierdie massale groei is byna uitsluitend behaal onder die primitiewe stamme ten suide van die Sahara. Ten noorde daarvan is onder die Moham- medane byna geen noemenswaardige ingang gevind nie.

Dit wil dan ook voorkom of die paganistiese godsdiens van die primitiewe stamme ten suide van die Sahara nie kan stand hou teen die aanslae van die Westerse beskawing en die Christendom nie. Dit blyk verder dat die tempo van die vordering slegs afhang van die mate waarin werkkragte in die veld gestoot en gewerk word.

Van die ongeveer 223 miljoen inwoners in Afrika is egter nog ongeveer 190 miljoen heidene, en in die noorde is daar nog 'n aaneengeslote blok van meer as $\mathbf{8 0}$ miljoen Mohammedane, terwyl ten suide van die Sahara die Christene oral klein minderhede vorm.

2. Die Islam en Kommunisme.

Die Christendom kon nog feitlik geen ingang vind by die Islamitiese bevolkings, en waar die Christendom en Islam in kompetisie is by die heidense stamme, maak die Christendom weinig vordering. Die Islam, wat geen rassediskriminasie ken nie en wat reeds gewortel is in Afrika, word gepropageer as die swart man se godsdiens. Dit pas ook baie aan by die heidense opvattinge en gebruike, en vir opname word geen eis van bekering gestel nie. Die toekoms van die Christendom in Afrika hang tot ' $n$ groot mate daarvan af in hoever die verdere voortgang van die Islam na die suide gestuit kan word.

Die imperialistiese droom van Nasser e.a. van een groot Arabiese staat in Afrika is 'n geweldige stimulus tot Mohammedaanse sendingaksie, en daar word beweer dat tussen 1954 en 1955 meer as 2,000 Islamitiese sendelinge deur die Al-Ashar-universiteit te Kairo 
opgelei en uitgestuur is vir sendingwerk onder die primitiewe stamme van Afrika en dat die Islam in 1958 £17miljoen vir 'n moslimse sendingaksie in Afrika gereserveer het.

Aan die ander kant is daar die Kommunisme met 'n netwerk van propagandistiese aksie dwarsdeur Afrika om die nie-blanke nasionale aksie te steun teen die koloniale magte. En hoewel die naturelle van Afrika tot dusver nie vatbaar is vir die leerstellings van die Kommunisme nie, word op hierdie manier die gees van ontevredenheid en 'n gevoel van frustrasie en verset teen die blanke gesag verder aangeblaas en aan die lewe gehou.

3. Die Kwalitatiewe Aspek.

(a) Die Positiewe Aspek:

Die vraag is egter in hoever die Protestantisme reeds wortel geskiet het in Afrika en in hoever daar 'n geïntegreerde Christelike en kerklike lewe opgemerk kan word. Om oor die kwalitatiewe diepte van die Christendom 'n juiste oordeel te vorm, is nie so maklik as om die kwantitatiewe vooruitgang daarvan te bepaal nie, maar dit is vanselfsprekend dat die laaste nog geen waarborg is vir die bestaan van 'n oortuigde en gevestigde Christendom nie.

Tog is daar tekens dat, mits die sendingaksie met alle krag voortgesit word, die Protestantisme 'n groot toekoms in Afrika het, mits sekere nadelige faktore, waarop ons later terugkom, uitgeskakel of geneutraliseer kan word.

Ons grond hierdie stelling op die volgende feite en oorweginge. In die eerste plek bied die vinnige uitbreiding van die Christendom in Afrika 'n belangrike basis vir verdere voortbou. Verder is dit van groot betekenis dat groot kerke met duisende lidmate reeds selfstandig is of vinnig op weg daarheen is.

Honderde voorbeelde kan genoem word van naturelle wat ten spyte van die hewigste vervolging pal gestaan het by die Christelike geloof.

Ook is daar baie voorbeelde van lidmate en gemeentes wat met groot volharding en opoffering sendingwerk onder hulle eie mense gedoen het. Uniek is die optrede van kragtige oortuigde figure wat, met net die Skrif in die hand, ver en wyd geloop het om die nie-Christene tot bekering te roep, sodat duisende op die wekroep van hierdie sogenaamde profete bekeer is. Bekend is die sprekende herlewings ("revivals”) in baie gemeentes na 'n periode van insinking, waarna duisende in groot berou besluit het om hulle te bekeer.

'n Feit van besondere betekenis is dat die Bybel of gedeeltes daarvan reeds in meer as 400 van die $\mathbf{5 0 0}$ tale in Afrika vertaal is en dat Christelike lektuur op groot skaal versprei word. Waar die laaste in aantreklike vorm aangebied word, word dit ook met gretigheid gelees - soos blyk uit die verspreiding van die African Challenge wat ' $n$ oplaag van meer as 100,000 het (uitgegee in Nigerië).

Die meeste politieke leiers in Afrika is Christene of produkte van sendingskole. Deurdringing van Christelike gedagtes en opvattinge in die heidense lewe ontbreek ook nie. So aanvaar die meeste heidene die God van die Skrif as bestaande, word op baie plekke die sabbat aanvaar as dag van rus e.d.m.; 
daar is stamme soos bv. die Tswana van Khama wat Christelike wette van krag gemaak het.

Oor die gehalte van die Christelike lewe self kan nie sommer dogmaties 'n oordeel gevel word nie. Na raadpleging van byna alle bronne daaroor en op grond van eie ervaring is ons van gedagte dat die volgende 'n redelike korrekte konklusie is.

Hoewel die meeste Christene slegs nomineel gekersten is, is daar baie voorbeelde van opreg Christelike individue met 'n oortuigde Christelike geloof en lewenswandel. Die meeste van hierdie Christene het 'n kinderlike geloof in God dat $\mathrm{Hy}$ hulle as sy volk aangeneem het, terwyl hulle ook daarvan oortuig is dat hulle na hulle dood die ewige saligheid binnetree.

In elke gemeente is daar ' $n$ kern van gelowiges wat, hoewel hulle nie in alles voldoen aan die Christelike standaard nie, tog beskou moet word as ware Christene. Hulle mag in baie opsigte faal, maar hulle doen hulle bes om versoekinge te weerstaan en Christelik te lewe. Hulle het gewoonlik enige karaktervastheid en neem baie selde hulle toevlug tot magiese middels. Baie handhaaf 'n Christelike monogame huwelik. Hulle is nie almal sulke gereëlde kerkgangers nie, maar hulle besef die geestelike louheid van die kerk en hulle erken hulle eie foute en gebreke. In tye van krisis kan op hulle gereken word.

(b) Die Skadusy:

Maar om die saak in die regte perspektief te sien is dit ook nodig om te let op die ernstige skadusye van die
Protestantisme onder die nie-blankes van Afrika.

In die eerste plek moet opgemerk word dat die kerke nog nie sonder die hulp van blanke sendelinge en kapitaal oor die weg kan kom nie. Waar kerke selfstandig is, word die pastorale sorg in die reël verwaarloos, is die prediking gewoonlik van 'n swak gehalte en vind sendingwerk weinig plaas.

Die meeste Christene vind dit moeilik om die Bybel te verstaan. Dit is nie vir hulle 'n lig in die lewe en hulle is nie bybelvaste Christene nie.

Die oorgrote meerderheid sogenaamde Christene is slegs nomineel gekersten en die meeste vertrou ook nog op magiese middele, glo aan die mag van towenaars en dat die afgestorwe voorouers buitengewone potensialiteite besit. God is in die eerste plek vir hulle die transendente God wat Hom nie baie bemoei met die gewone lewe nie.

Sinkretisme van heidense gedagtes en gebruike met die Christendom het in die baie Sionistiese sektes 'n nuwe godsdiens geword, waarin die ou magiese gebruike en opvattinge, los van hulle geestelike en sosiale agtergrond, alle ware godsdienssin versmoor en bedenklike vorme aanneem.

Vir die meeste is die Christelike kerk 'n wesenlik vreemde instelling waarin hulle hulle nie kan uitlewe en hulle geloof tot volle uitdrukking kan bring nie.

Godsdiens is geskei van die lewe en het vir die meeste geword 'n uitwendige saak van die nakoming van sekere seremonies.

Die sedelike lewe van die meeste Christene is net soos dié van die hei- 
dene van ' $n$ baie lae gehalte. Daar is min jong mense bo 14 jaar wat nie reeds seksuele gemeenskap gehad het nie, en waar swangerskap van 'n vrou voor die huwelik vroeër op verskillende maniere teengewerk en afgekeur is, wek dit nou geen besondere kommentaar nie.

Die teologiese opleiding voldoen op verre na nie aan die standaard wat daarvoor gestel moet word nie en is in die reël bloot 'n oordra van die teologiese begrippe en inhoud soos dit vorm gekry het in die Westerse teologie, sonder inagneming van die konkrete agtergrond en werklikheid van die naturelle-omgewing.

'n Bybelvaste Christendom kan dus ook nie verwag word met sulke geestelike leiers nie, en die toekoms van die Christendom word in gevaar gestel as verbeteringe nie aangebring word nie.

Daar is nog nie soos in die ooste 'n strewe om die Christelike waarheid in 'n eie belydenis vas te lê nie en daar is ook nie soos in die ooste teologiese denkers wat iets van teologiese waarde gelewer het nie.

\section{(c) Konklusie:}

Ons het dus te doen met baie ernstige gebreke in hierdie Protestantse Christendom, maar in hierdie donker prent is daar ook ligpunte wat vir iets beters laat hoop.

Van besondere betekenis is dat die gebreke in die kerk al meer besef word en dat die Christelike gewete onrustig word oor die sedelike verval, die louheid en swak sendingbesef. Dit moet ons bewondering wegdra dat in so ' $n$ verpeste omgewing daar nog Christene is wat 'n hoogstaande sedelike lewe lei en dat daar nog so baie jong mense is wat die versoekinge weerstaan en die moed besit om teen die publieke opinie in te gaan.

Dat nog die toevlug geneem word tot magiese middele is op sigself nie juis so onrusbarend nie, mits dit slegs die gevolg is van die beswyking vir versoekinge in 'n origens geïntegreerde Christelike lewe.

Iemand wat soms sy toevlug hiertoe neem, kan dus nie sommer as 'n ongelowige gebrandmerk word nie, ook nie as sy sedelike lewe nie in alles beantwoord aan die Christelike norme nie .

Bemoedigend is egter dat daar tekens is dat die inheemse Protestantse kerke die gevare van die heidendom in die kerk begin besef en dit wil bestry.

Die teologiese opleiding is nog nie wat dit moet wees nie, maar daar word dwarsdeur Afrika energieke poginge aangewend om hierin verbetering aan te bring.

Die Protestantse kerk is wesenlik nog ' $n$ vreemde instelling vir die meeste naturelle, maar waar hulle vroeër die eintlike Christendom daarin gesien het dat dit in alles bloot 'n kopie moes wees van die Westerse vorme en organisasie, begin die meer denkende naturelle nou eindelik self soek na weë om die kerk te laat inpas in die naturelle-lewe en te laat spreek vir die konkrete inheemse omgewing.

Op grond van die genoemde gunstige faktore en die feit dat die Protestantse kerke self onrustig word oor die gebreke, kan gekonstateer word dat, hoewel die Protestantisme nog nie 'n geïntegreerde lewensbeskouing en optrede en geloof gevorm het nie, daar alle hoop is dat dit met 'n rustige 
ontwikkeling mettertyd kan uitgroei tot 'n op die Skrif gewortelde en geankerde geloof. Die oorgang van 'n volk van die heidendom tot die Christendom is, soos geblyk het uit die kersteningsproses van ons eie blanke voorouers in Europa, nie 'n saak van enkele jare of een geslag nie, maar van geslagte.

Daar is veral drie faktore wat sodanige ontwikkeling onseker maak, en dit is die sinkretistiese neiging wat nie in al sy diepte deurpeil word nie, die onchristelike sekularisering van die lewe en die ongesonde rasseverhouding.

\section{PROBLEMATIESE VOORUITSIGTE.}

(1) Rasseverhoudinge:

Hoofsaaklik as gevolg van die nasionale ontwaking veral by die meer ontwikkelde naturelle, het daar 'n diepgaande verwerping van alle rassediskriminasie of alle sweem van sodanige ongunstige onderskeiding by die nieblankes ontstaan. Die meer ontwikkelde naturelle begin hulle rug op die kerk draai en daar begin 'n onrusbarende wegstroming weg van die kerk by hierdie element plaasvind. Hulle is teleurgesteld in die kerk omdat dit volgens hulle nie toepas wat dit preek nie en hulle verwag dat die kerk hulle moet steun in hulle vrywordingstrewe. Daar is ook 'n neiging by baie van hulle om die kerk te verwerp op grond daarvan dat dit ' $n$ blanke instelling is wat slegs gepropageer word vir die verdere verslawing van die naturelle.

Hulle verlang 'n eiesoortige ontwikkeling, maar dan in alles 'n volwaardig moderne ontwikkeling; alle tekens van rassediskriminasie sien hulle as 'n afskuwelike teenstrydigheid met die Christelike leer.

Hierdie rasseprobleem met alles wat dit inhou, word deur God self voor die aandag van die kerk geplaas en $\mathrm{Hy}$ verwag 'n antwoord van die kerk op die vraag. 'n Kerk is alleen Christelik as dit met sulke konkrete probleme worstel en die uitweg soek. Daarom sal die kerk onbevreesd die lig van die Woord van God in hierdie nuwe situasie moet laat skyn sodat die naturellewêreld dit hoor as Sy Woord.

Sonder die nodige goeie verhoudinge kan dit moeilik verwag word dat die Christendom aanneemlik gemaak kan word vir die naturelle. Die regte Christelike gesindheid teenoor die naturel moet sterker spreek en in toepassing gebring word, die kerk moet meer word 'n kerk vir en van die naturelle, en naas die beginsel van eiesoortigheid moet die eenheidsbeginsel in Christus meer op die voorgrond gestel word. Nie selfstandige kerke, los en apart van die blanke kerke, moet as ideaal gestel word nie, maar aparte kerke in blywende verband met laasgenoemde.

\section{(2) Sinkretisme:}

Die Here konfronteer die kerk ook met die probleem van sinkretisme, sodat die kerk teenoor hierdie konkrete werklikheid stelling kan inneem en die stryd kan aanbind. Gewoonlik egter word die sinkretistiese neiginge by die naturelle of geheel en al geignoreer of bloot veroordeel. Die gevolg van so 'n optrede sal wees dat daar steeds 'n spontane sinkretisme in werking sal wees; dat baie gedryf word na sinkretistiese sektes en dat met die groeiende nasionale besef daar ook uiteindelik 
gesoek kan word na 'n sinkretistiese nasionale godsdiens of ook dat die Islam, wat in teenstelling met die Christendom voorsiening maak vir sulke situasies waarin 'n naturel gedryf word, tot die inroeping of verkryging van magiese hulp, die naturelle-wêreld kan oorrompel.

Blote ignorering of veroordeling hou dus baie gevare in, en die enigste juiste houding is om te probeer om die probleem in al sy volle diepte te verstaan, erns daarmee te maak en die Skrifwaarheid te laat spreek vir die konkrete wêreld van die naturel.

Waar verskillende godsdienste mekaar ontmoet op 'n substratum van primitiewe religiositeit, ontstaan daar gewoonlik 'n sinkretistiese vermenging. Dit word in die hand gewerk deur de opvatting van die primitiewe mense dat die numineuse aangewend kan word om die lewe te bevorder of te beskadig. Elke religieuse materiaal van 'n godsdiens kan die vereiste geheime krag verleen. En so kan gesê word dat die sinkretistiese neiging by Christelike naturelle daaruit verklaar kan word dat hulle uit utiliteitsoorweginge soms ook hulle toevlug neem tot magiese hulp en dat heidene soms ook tot God wil bid, of versoek dat vir hulle gebid word.

Die sinkretistiese diepte word nog nie deur hierdie utiliteitsvroomheid ten volle gepeil nie.

Ons kan dit alleen leer begryp as ons onsself in die plek van die naturel stel wat in sy primitiewe religiositeit, waarin hy nog met baie vesels verbind is, ware lewe en beweging soek in die integrasie van die mens in die totaliteit van die kosmiese en natuurlike orde.
Die mens is self ' $n$ deel en aspek van die natuurorde net soos die gode en die gemeenskap. Daar is dus wesenlik geen absolute godsdiens nie.

Nou word sinkretisme alleen 'n probleem as dit gekonfronteer word met die absolute waarheid van die Woord van God, wat geen relativisme ken nie.

Hierdie sinkretistiese drang kan alleen oorwin word as dit konstant met die waarheid gekonfronteer word soos dit spreek uit die Woord van God en as die Evangelie van Jesus Christus ook spreek in die konkrete lewe van die naturel.

Nou is dit egter diep tragies dat in die Christendom, soos dit tot die naturel gebring word, die godsdiens en die lewe geskei word, en so kan hierdie sinkretisme moeilik oorwin word. Vir die naturel kan godsdiens en die kultuur en die lewe nie geskei word nie. Aangesien die gesekulariseerde Westerse kultuur, wat in die oë van die naturel ook deel is van die Christelike godsdiens, deur sy onchristelike karakter geskei word van die godsdienstige wortel, spreek die Woord van God nie vir die lewe buite die suiwer godsdienstige nie. Maar vir die naturel, vir wie godsdiens en die lewe so nou met mekaar verbind is, is dit ' $n$ onmoontlike toedrag van sake en daarom neem hy in sy lewens. moeilikhede die toevlug tot magiese hulp of selfs tot sy afgestorwe voorouers, wat ooreenkomstig hierdie primitiewe religieuse besef wel vir die daelikse lewe van betekenis is.

Die enigste werklike oplossing is dat die Christelike kerk onder die naturelle self leer om met hierdie probleem te worstel by die lig van die Woord van 
God, dat dié Woord ook die lig word vir die hele lewe en Christus die verlosser in alle lewensituasies.

Om die nie-blankes in hierdie stryd te help sal daar ook goed opgeleide sendelinge moet wees wat in kontak met die religieuse agtergrond van die heidene 'n deeglike studie daarvan gemaak het.

Eindelik moet die kerk vir die nieblankes beantwoord aan sy wese van 'n nuwe herbore mensheid wat, hoewel dit nie van die wêreld is nie, tog solidêr daarmee is; alleen hierdie kerk kan en moet die antwoord vind vir sy eie omgewing. Om so te kan optree moet dit 'n kerk wees wat in verband staan met sy omgewing en 'n eie karakter dra en as 'n eie kerk aangevoel word met 'n eie roeping teenoor die eie omgewing, en met ' $n$ eie geloofsuitdrukking.

\section{(3) Sekularisme:}

Hierdie sinkretisme kan oorwin word deur die Christendom, maar ook deur die onchristelike sekularisme. Die laaste sien ons in die geval van die meer ontwikkelde ongelowige naturelle. Die Westerse tegniek en wetenskap moet hulle nou op die lewensweg die nodige hulp bied, en nie die godsdiens of magie nie. Was dit nie vir hierdie onchristelike sekularisme wat naas die Christendom in die primitiewe wêreld ingestroom het nie, sou die toekoms van die Protestantisme in Afrika nog, ten spyte van die ander ongunstige faktore, belowend bly, want hierdie sekularisme is die eintlike dodelike gevaar vir die Christendom in Afrika.

Ons spreek van 'n onchristelike sekularisme, want daar is ook 'n
Christelike sekularisme. Christus immers het gekom om die natuur- en gemeenskapsverbonde primitiewe mens te bevry van sy bande en sy lewe te sekulariseer. Christus lei hierdie mens tot emansipasie uit sy natuurgebondenheid en tot vryheid uit die slaafse bande van die gemeenskap deur die mens aan Homself te verbind in ' $n$ nuwe integrasie met die mensheid en die wêreld. $\mathrm{Hy}$ laat ontstaan ' $n$ individuele verantwoordelikheidsbesef, 'n waardering van die persoonlike, medelyde met die lydende. $\mathrm{Hy}$ lei tot mondigheid en 'n innerlike verhouding tot God, 'n diepe normbesef waaruit volg ontevredenheid met alles wat teen die norm stry soos uitbuiting, slawerny, die slaafse posisie van die vrou. Hy laat ontstaan 'n verhouding van ware liefde tussen man en vrou, en die seksualiteit word 'n uitdrukking van liefdesgemeenskap tussen man en vrou, en $\mathrm{Hy}$ gee sin en doel aan die geskiedenis. Die arbeid word 'n seën, die mens word geroep om die natuur te beheers en die wêreld as 'n eenheid te sien.

Die Christelike boom wat in Europa geplant is, het ook hierdie vrugte van die Christelike sekularisasie gedra, en die onchristelike sekularisasie, wat as die antitese en die anti-christelike daarvan van hierdie boom afgesplits is, kan weerstaan word omdat dit 'n groeisel is in hierdie Christelike agtergrond en daarteenoor 'n Christelike sekularisme gegroei het.

Maar nou wys dr. Berkhof daarop dat die diep tragiese van die saak is dat die vrugte van hierdie boom, sonder die boom, in Afrika oorgeplant word, sonder dat die Christendom voldoende geleentheid gehad het om in Afrika 
wortel te skiet en 'n geïntegreerde Christelike lewe bewerk is.*

Die vrugte word oorgedra, maar sonder God, en so lei die vryheid tot outonomie; die waardering van die individuele persoonlikheid lei tot atomisering van die lewe. Tegniek word die mag wat die mens aan homself verslaaf en die arbeid word die afgod om daardeur die lewe te verryk en te verbeter; seksualiteit word 'n prikkel om die eie luste te bevredig, ens.

Hierdie sekularisme dryf die ou heidendom uit en vervang dit. Dit word ingeënt op volksliggame wat nog hoofsaaklik naturalisties is, terwyl die Christelike boom, waaraan die vrugte moet groei, nog nouliks oorgeplant is.

Die gevolg is dat die primitiewe mens se lewe heeltemal ontwrig en ontwortel word.

Hierdie sekularisme kan volgens dr. Berkhof alleen lei tot anargisme en nihilisme of na ' $n$ welbewuste soeke na Christus wat gekom het om die lewe te sekulariseer en in wie se diens hierdie gesekulariseerde lewe alleen vir die nihilisme behoed word.

Maar, so konkludeer dr. Berkhof, sal die enige heilsame moontlikheid in vervulling gaan, dan sal naas die hulp aan onderontwikkelde gebiede die Christusprediking deur die sending, die jong kerke en die wêreldkerk met ongeëwenaarde krag aangepak moet word. Sonder hierdie antidotum kan die huidige inenting ons maar net die ernstigste siekteverskynsels laat verwag.

HUGO DU PLESSIS.

P.U. vir C.H.O.

* H. Berkhof - Christus de zin der Geschiedenis bl. 75 e.v.

\section{GERAADPLEEGDE LITERATUUR.}

Anderson, W.: Towards a Theology of missions, Londen 1955.

Bavinck, J. H.: The Impact of Christianity on the non-Christian World, Grand Rapids. 1948.

Groves, C. P.: The Planting of Christianity in Africa (veral die 3de en 4 e dele), Londen, 1955-58.

Hunter, M.: Reaction to Conquest, Londen. 1936.

Kraemer, H.: The Christian message in a non-Christian world, Londen. 1938.

Lamott, W. C.: Revolution in Missions, New York. 1958.

Parrinder, G.: African Traditional Religion, Londen. 1958.

Philips, A. ed.: Survey of African Marriage and Family Life, Londen. 1953.

Price, T.: African Marriage, Londen. 1954, 1955, 1956.

Schapera, E., ed.: Bantu-speaking Tribes of S.A., Kaapstad. 1937.

Shepperson, G. and Price, T.: Independent African, Londen. 1958.

Sundhler, B. G. M.: Bantu Prophets in S.A., Londen. 1945.

Taylor, J. V.: The Growth of the Church in Buganda, Londen. 1958.

Taylor, J. V.: Processes of Growth in an African Church, Londen. 1958.

Trimmingham, J. S.: Islam in West Africa, Londen. 1958.

Trimmingham, J. S.: The Christian Church and Islam in West Africa, Londen. 1955.

Westermann, D.: Africa and Christianity, Londen. 1935.

Wiseman, E. M.: Kikuyu Martyrs, Londen. 1958. 